\title{
ANTAGONISM OF TRICHODERMA SPECIES ON CLADOSPORIUM HERBARUM AND THEIR ENZIMATIC CHARACTERIZATION
}

\author{
Maria Angélica G. Barbosa'*; Kurt Georg Rehn²; Maria Menezes²; Rosa de Lima R. Mariano² \\ ${ }^{1}$ Departamento de Agronomia/Fitossanidade; Universidade Federal Rural de Pernambuco, Recife, PE, Brasil. \\ ${ }^{2}$ Departamento de Bioquímica, Universidade Federal de Pernambuco, Recife, PE, Brasil.
}

Submitted: August 21, 2000; Returned to authors for corrections: November 16, 2000; Approved: February 02, 2001

\begin{abstract}
The verrucose caused by Cladosporium herbarum reduces production and quality of Passion fruit (Passiflora edulis Sims.), a largely consumed tropical fruit. This work aimed to investigate the antagonism of Trichoderma species (T. polysporum, T. koningii, T. viride and T. harzianum) against Cladosporium herbarum, and to study the production of extracellular hydrolytic enzymes by the pathogen and the antagonists. The results showed considerable antagonistic potential for the biocontrol of $C$. herbarum isolates by all Trichoderma species, except $T$. koningii. The most distinguished effect was observed for T. polysporum. In relation to the pattern of esterase obtained by electrophoresis in poliacrylamyde gel, the major activity presented by the isolates was observed after five days of incubation. The $C$. herbarum isolates produced extracellular enzymes, lipase, pectinase, cellulase, and protease, all possibly related to the infection process. Amylase excretion, not known to be associated with phytopathogens, was detected in Trichoderma species, but not in C. herbarum. In addition to amylase, all Trichoderma species tested produced also extracellular cellulase and pectinase, except $T$. koningii in relation to the latter enzyme. The demonstration of various esterase isoenzymes in zymograms of the Trichoderma species and $C$. herbarum isolates was markedly improved by washing the mycelia with detergents or EDTA. This fact suggested that a major fraction of extracelular enzymes may remain attached to outside fungal cell wall after being excreted.
\end{abstract}

Key words: passion fruit, biological control, extracellular enzymes, fungi

\section{INTRODUCTION}

Cladosporium herbarum (Pers: Fr.) Link is considered a saprophyte that turns into a plant pathogen in various stress conditions $(15,16,21,40)$. It produces rot diseases in a number of important fruit crops, e.g. pear, grape and cherry, surface mold on raisins and figs, and also damages corn and rye. Its teleomorph, Mycosphaerella tassiana (De Not.) Johans is responsible for the brown leaf spot disease of date palm (9). Cladosporium herbarum occurs in Brazil (3) as an important pathogen on passion fruit (Passiflora edulis Sims.) causing the verrucose symptoms, reducing the production and fruit quality (Fig. 1).

In general, the use of chemicals is effective in the control of several fungal plant diseases, but there is not report of an efficient fungicide in relation to verrucose disease of passion fruit. Preliminary studies testing the possibility to use biological agents, such as antagonistic species from the genus Trichoderma are reported in the literature $(10,43)$. These species are well studied and have shown efficience on biocontrol of different phytopathogens $(8,20,31,36,37)$, including some from phyloplane, such as Botrytis (Pers. Ex Fr.), Cladosporium, Sclerotinia Fuckel and Alternaria Nees (4). Nowdays a biofungicide formuled with T. harzianum, named Trichodex, is used to control soilborne and phyloplane pathogens and other formulations, such as Binab-T, GlioGard and RootShield, are used to control several soilborne pathogens which cause damping-off and root rot $(24,43)$.

Considering the importance of both pathogen and host, the purpose of this work was to study the antagonistic potential of

\footnotetext{
* Corresponding author. Mailing address: Universidade Federal Rural de Pernambuco, Departamento de Agronomia, Área de Fitossanidade. 52171-900; Recife, PE, Brasil. E-mail: angelica@nelore.npde.ufrpe.br
} 


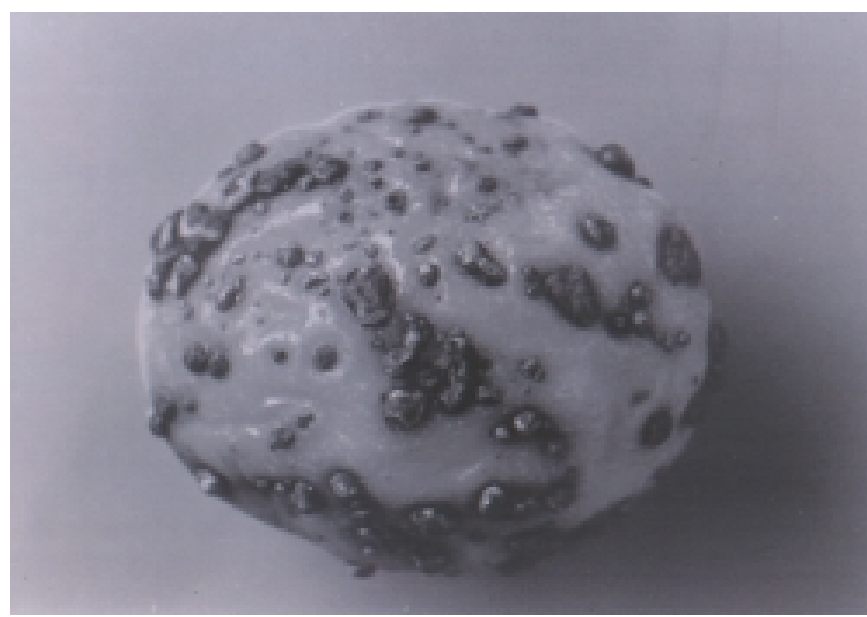

Figure 1. Symptoms induced by Cladosporium herbarum on passion fruits.

Trichoderma species against $C$. herbarum, and the capacity of pathogen and antagonist to produce extracellular enzymes that could be related to the mechanism of pathogenicity or antagonistic activity.

\section{MATERIALS AND METHODS}

\section{Fungal isolates}

Four isolates of $C$. herbarum designated Ch-1, Ch-2, Ch-3, and $\mathrm{Ch}-5$, obtained from passion fruits showing verrucose symptoms, and four Trichoderma species, T. polysporum (T-11), T. koningii (T-15), T. harzianum (T-25) and T. viride (TR-2) from the collection of Laboratory of Phytopathogenic Fungi, Agronomy Department from Universidade Federal Rural de Pernambuco, were studied.

All isolates were grown on standard PDA (42), at $26^{\circ} \mathrm{C}$ and $60 \%$ of relative humidity, for three days (Trichoderma) and ten days ( $C$. herbarum), in order to obtain young colonies for the studies on antagonistic and enzimatic activities.

\section{Antagonistic activity}

The effect of non-volatile metabolites from Trichoderma species against $C$. herbarum was tested by the method described by Lundberg and Unestan (33), and Dennis and Webster (12). Initially, mycelial agar plugs (6 mm diameter) removed from the edge of a young culture of Trichoderma species were transferred to the center of Petri dishes (10 mm diameter) containing PDA and a sterilized cellophane disc ( $10 \mathrm{~cm}$ diameter) adjusted on the medium surface, where the antagonist grown for $60 \mathrm{~h}$. Then the cellophane containing the Trichoderma growth was removed, and on the same medium a disc of each pathogen isolate was placed. The control treatments had $C$. herbarum growing similarly on PDA medium where previously there was a cellophane disc without antagonist.
The effect of volatile metabolites from Trichoderma species against $C$. herbarum was tested in the assemblage described by Dennis and Webster (13). Two bottons of Petri dishes containing PDA were individually inoculated with a disc of pathogen and antagonist, and bottons were adjusted and attached by tape. The control sets did not contain the antagonist. The cultures were incubated at $26^{\circ} \mathrm{C}$ and $60 \%$ relative humidity under alternating luminosity (12 h light/12 h darkness). The studies of non-volatile and volatile metabolites were conducted in four replications arranged in a randomized design.

Growth rates, in both assays, were recorded daily by measuring colony diameter according to Lilly and Barnett (32). The inhibition percent was obtained using the formula: $\mathrm{I} \%=[(\mathrm{C} 2$ -C1)/C2) ] x 100 (19), where C1 means growth of C. herbarum and $\mathrm{C} 2$ means growth of control.

The sporulation was evaluated using the Neubauer chamber, and the results were expressed in spore by milliliter of distilled water.

\section{Extracellular Enzymes}

Esterase profile was obtained by electrophoresis in polyacrylamide gel. The isolates of Trichoderma and $C$. herbarum were grown in potato dextrose broth under continuous luminosity, at $26^{\circ} \mathrm{C}$, for five and ten days, respectively. After these periods, $300 \mathrm{mg}$ of wet mycelium were suspended in $3 \mathrm{~mL}$ of 2 mM EDTA, pH 7.4 and left for 20 minutes at $26^{\circ} \mathrm{C}$. Cells were spun down for 1 minute, in an Eppendorf centrifuge and the supernatant was used.

For comparison, the fluid was also tested, after filtering cells on a Whatman \#1 filter. Samples of extracts were applied in wells on the top of the gel. Bromophenol blue was added as a marker dye and then electrophoresis was carried out at 10 $\mathrm{mA}$ for $4 \mathrm{hr}$ at $4^{\circ} \mathrm{C}$. Gel was removed and stained with fast blue $\mathrm{RR}$ for $1 \mathrm{hr}$ under dark conditions at $37^{\circ} \mathrm{C}$. A relative mobility $(R f)$ value was assigned to each band of enzyme activity using the formula: $\mathrm{Rf}=(\mathrm{d} / \mathrm{D}) \mathrm{x} 100$, where " $\mathrm{d}$ " is the distance runned by the molecules in the gel, and " $D$ " is the distance runned by the marker dye (1).

The activities of other extracellular hydrolytic enzymes were detected on solid media by placing mycelial discs of Trichoderma species or $C$. herbarum isolates on the medium containing the enzyme substrate and measuring the zone of degraded substrate formed around the colony an after incubation period. Monoacyl esterase activity was studied using Tween 20 as substrate (26); amylase, using soluble starch (26); protease, using milk agar (44); and cellulase, using microcrystalline cellulose (39). Pectinolytic enzymes were assayed by isolates growing induction medium with citrus pectin during $72 \mathrm{~h}$ (35). In all these experiments, isolates of Trichoderma species and $C$. herbarum were incubated respectivelly, for two and five days, before measuring degradation halos, and the bioassays were done in quadruplicate. 


\section{RESULTS}

\section{Growth and fungal antagonism}

As showed in Fig. 2, no significant difference of mycelial growth was observed between individual isolates of Trichoderma species or between isolates of Cladosporium herbarum, respectively ( $\mathrm{p}>0.05)$. However, all species of Trichoderma grew considerably faster on PDA than the isolates of $C$. herbarum, in the same conditions of culture $(p>0.01)$.

When $C$. herbarum was cultivated in the same Petri dish, where previously Trichoderma was grown, antagonism was readily observed. Non-volatile substances were responsible for most of the growth inhibition and sporulation (Fig. 3 A, B). Considering growth inhibition by non-volatile toxins, our isolates of $T$. polysporum (T11) were more efficient than T. harzianum (T25) and T. viride (TR2) in retarding growth $(\mathrm{p}>0.01)$ and sporulation ( $p>0.05$ ) of $C$. herbarum. Of all Trichoderma species tested, $T$. polysporum was also the only one to produce some growth inhibition by volatile substances (Fig. 3 C). Most of the tests (Fig.

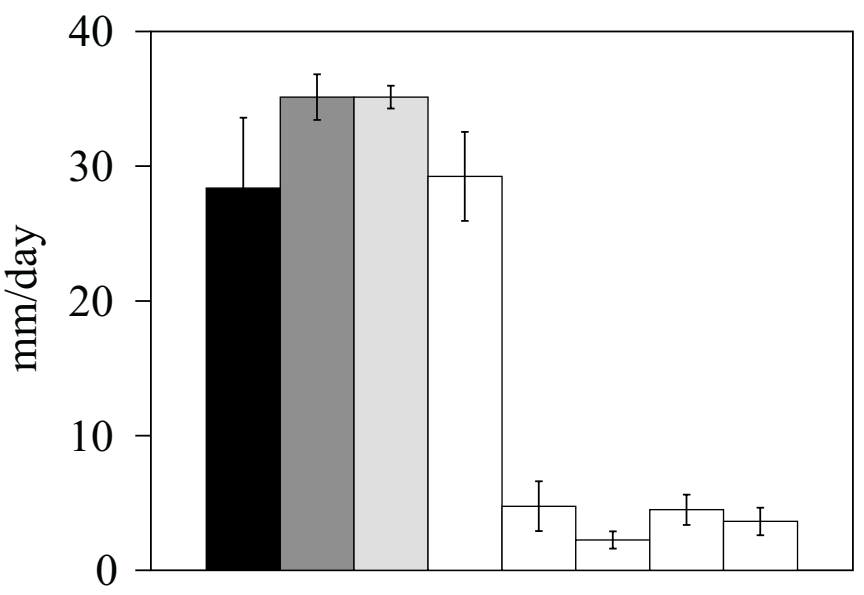

Figure 2. Mycelial growth of Trichoderma species and Cladosporium herbarum isolates on PDA. From left to right: $T$. harzianum; T. koningii; T. polysporum; T. viride, and C. herbarum isolates Ch-1, Ch-2, Ch-3 and Ch-5.

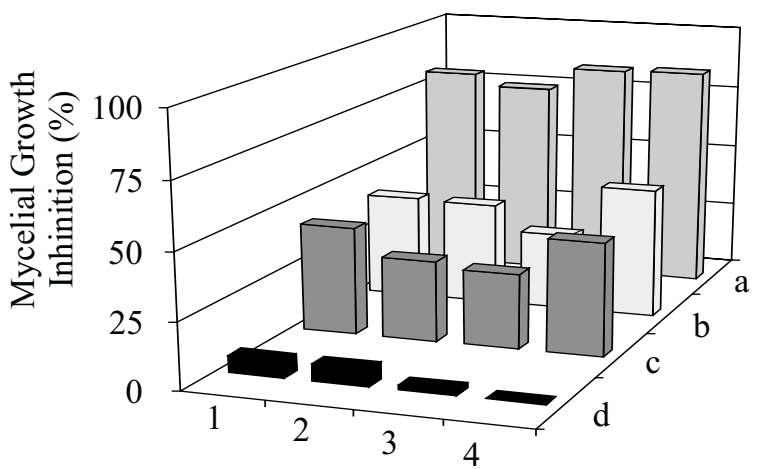

A

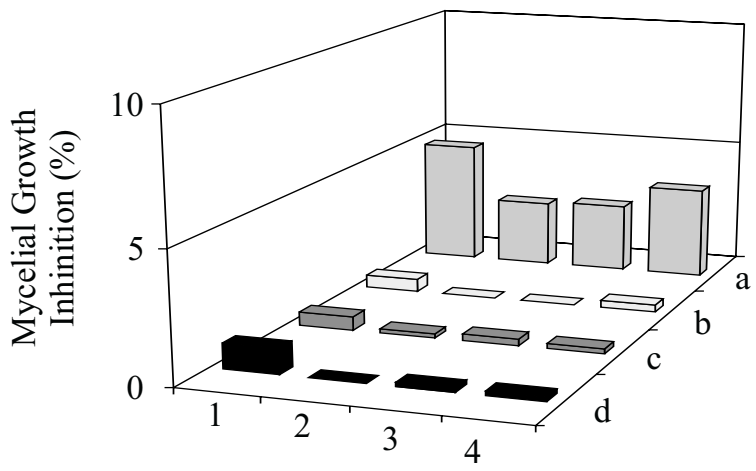

C

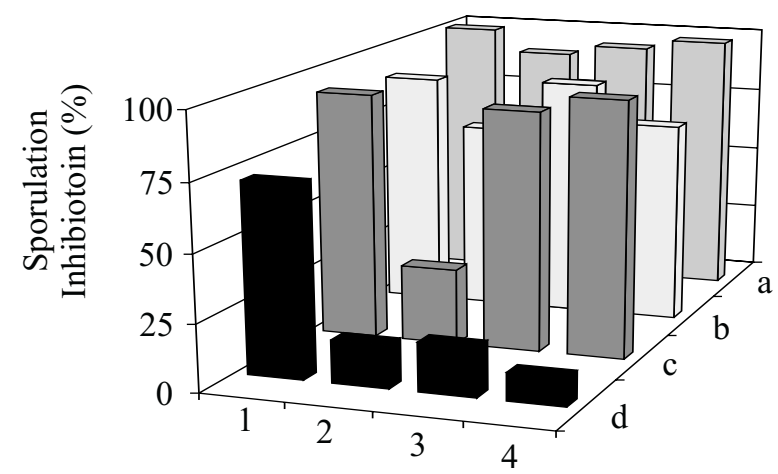

B

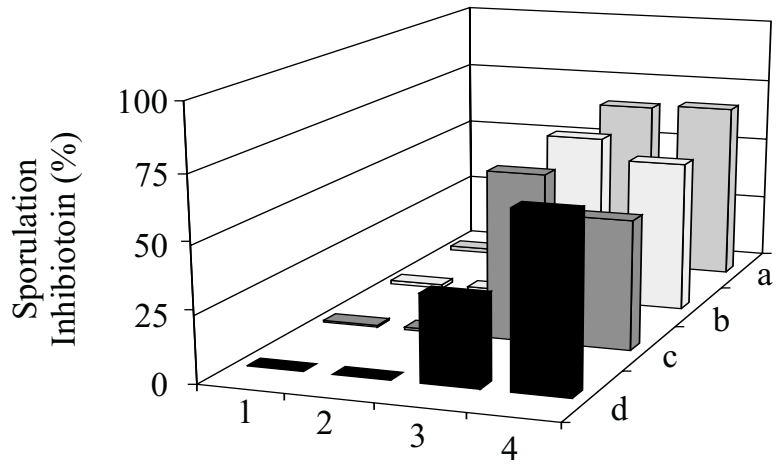

D

Figure 3. Inhibition of mycelial growth and sporulation of Cladosporium herbarum by non-volatile (A, B) and volatile (C, D) substances produced by Trichoderma species. Isolates of $C$. herbarum: $1=\mathrm{Ch}-1 ; 2=\mathrm{Ch}-2 ; 3=\mathrm{Ch}-3 ; 4=\mathrm{Ch}-5$. Isolates of Trichoderma spp. $\mathrm{a}=T$. polysporum $; \mathrm{b}=$ T. viride $; \mathrm{c}=T$. harzianum $; \mathrm{d}=T$. koningii. 
$3 \mathrm{~A}, \mathrm{~B}, \mathrm{C})$, showed an inferior performance of $T$. koningii (T15) as compared with the other species $(\mathrm{p}>0.01)$. On the other hand, when antagonism was observed for longer periods, all species of Trichoderma but T. polysporum produced inhibition halos and sporulated over the colonies of $C$. herbarum, at least in some of its four isolates. Interestingly, some remarkable differences in the interactions of the four isolates of $C$. herbarum with the species of Trichoderma attested the genuine differences between them. In relation to sporulation, $\mathrm{Ch} 2$ was much more resistant against $T$. harzianum than the other isolates and, in the same test, Ch1 demonstrated a rather selective sensitivity against dissolved metabolites of T. koningii (Fig. 3 B), In another assay, only Ch3 and $\mathrm{Ch} 4$ were affected by volatile substances of the four species of Trichoderma (Fig. 3 D).

Microscopic studies of antagonized Cladosporium isolates most frequently revealed wilt of mycelium and coagulated protoplasm, fragmented hyphae, shorter cells and thicker septa. Trichoderma spores within Cladosporium hyphae were also seen (Fig.4).

\section{Extracellular enzymes}

All isolates of $C$. herbarum produced much less cellulolytic activity ( $\mathrm{p}<0.01$ ) than the four species of Trichoderma (Fig. 5 A). Otherwise, pectinolytic enzymes were secreted in similar concentrations both by Trichoderma and C. herbarum isolates, with exception to T. koningii (Fig. 5 B). Protease and monoacyl esterase were exclusively found in filtrates of $C$. herbarum isolates (Fig. 6 A, B). On the other hand, only the species of Trichoderma secreted amylase (Fig. 6C).

The latter findings are possibly related to the observation, that naphtyl esterase zymograms, after electrophoresis of extracellular enzymes, showed bands of different mobility in

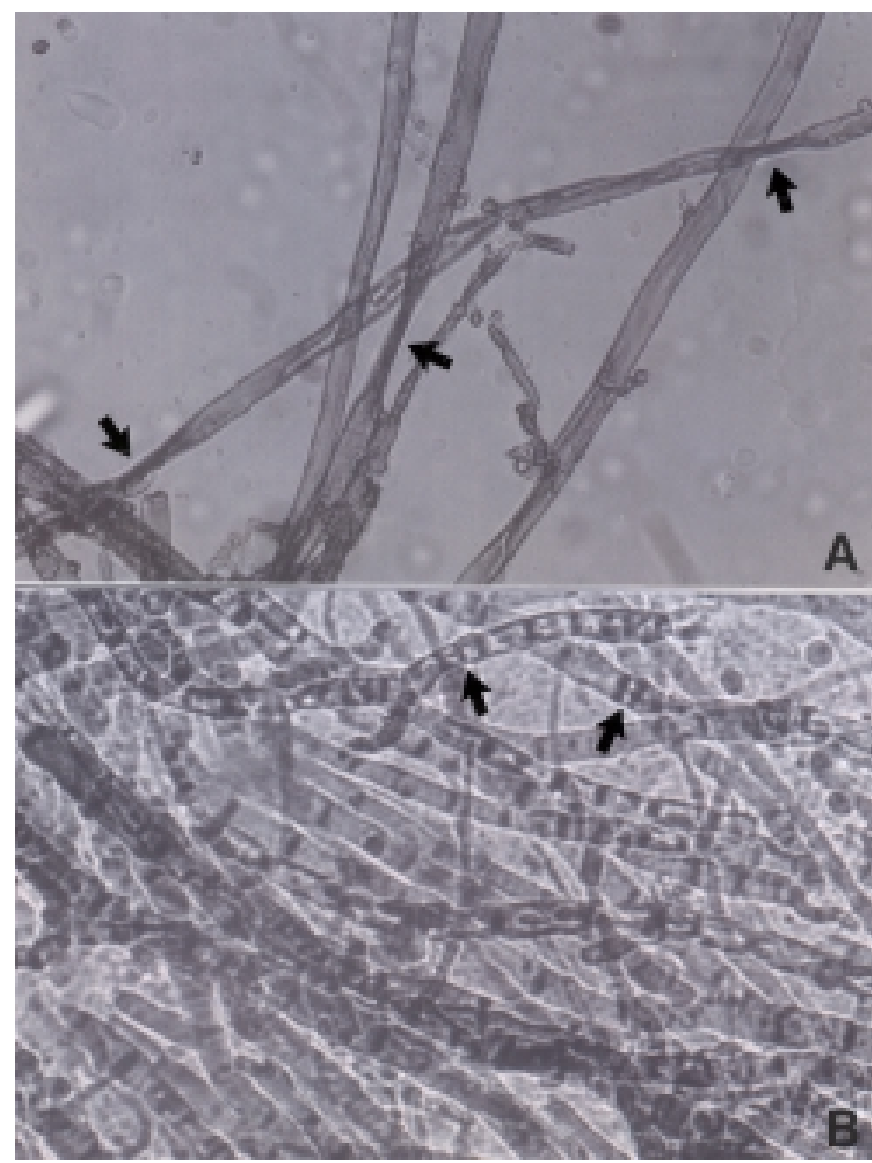

Figure 4. Morphologicals characteristics between Trichoderma spp. and Cladosporium herbarum: hyphal shrinking (A); cell shortening and septa thickening (B) of C. herbarum, in the presence of Trichoderma $(320 \mathrm{x})$.
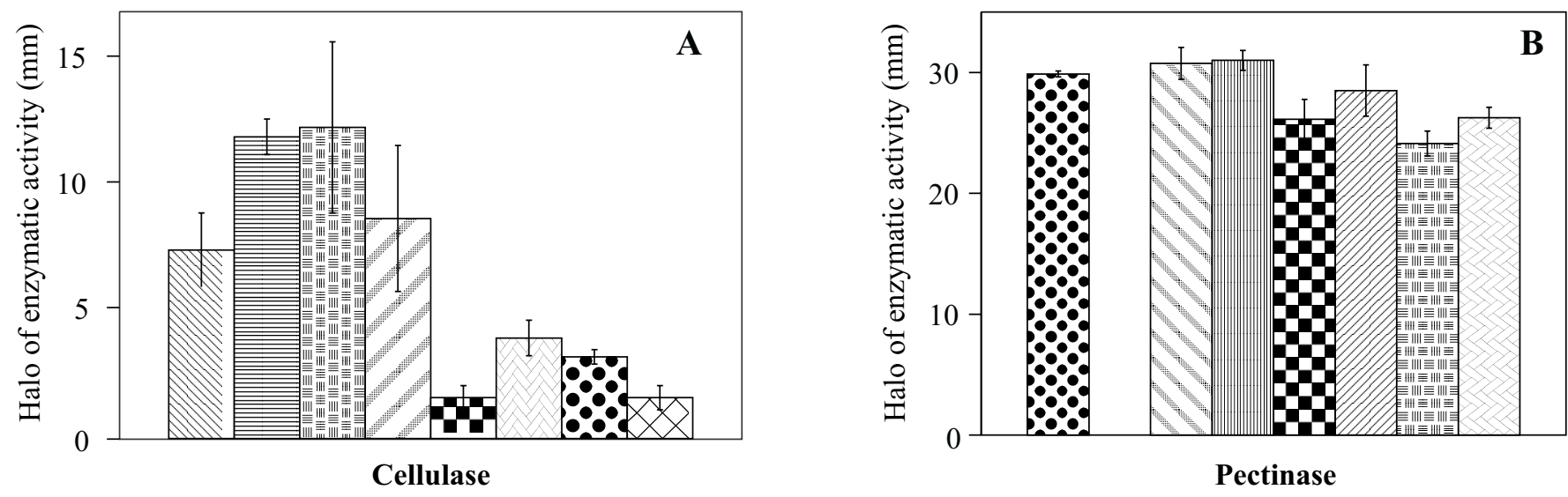

Figure 5. Production of plant cell wall degrading enzymes in semisolid media by Trichoderma spp. and Cladosporum herbarum isolates. From left to right: T. harzianum; T. koningii; T. polysporum; T. viride; isolates Ch-1, Ch-2, Ch-3 and Ch-5 of C. herbarum. The halo of enzymatic activity does not include the halo of the mycelium disc. 


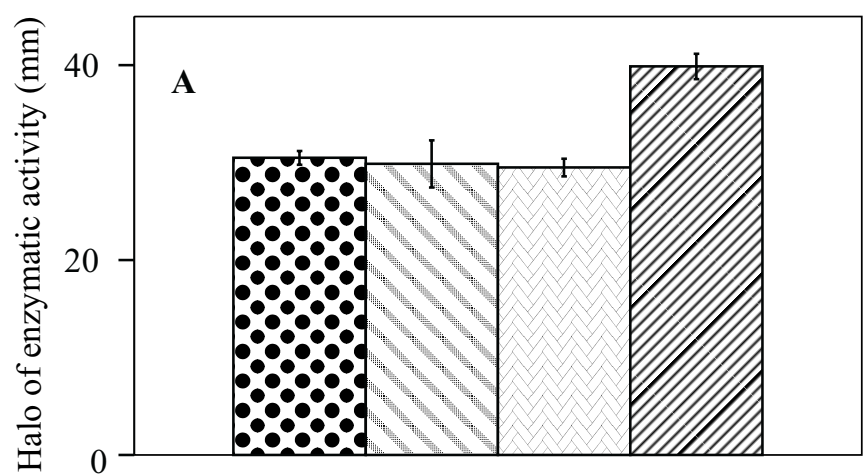

Protease
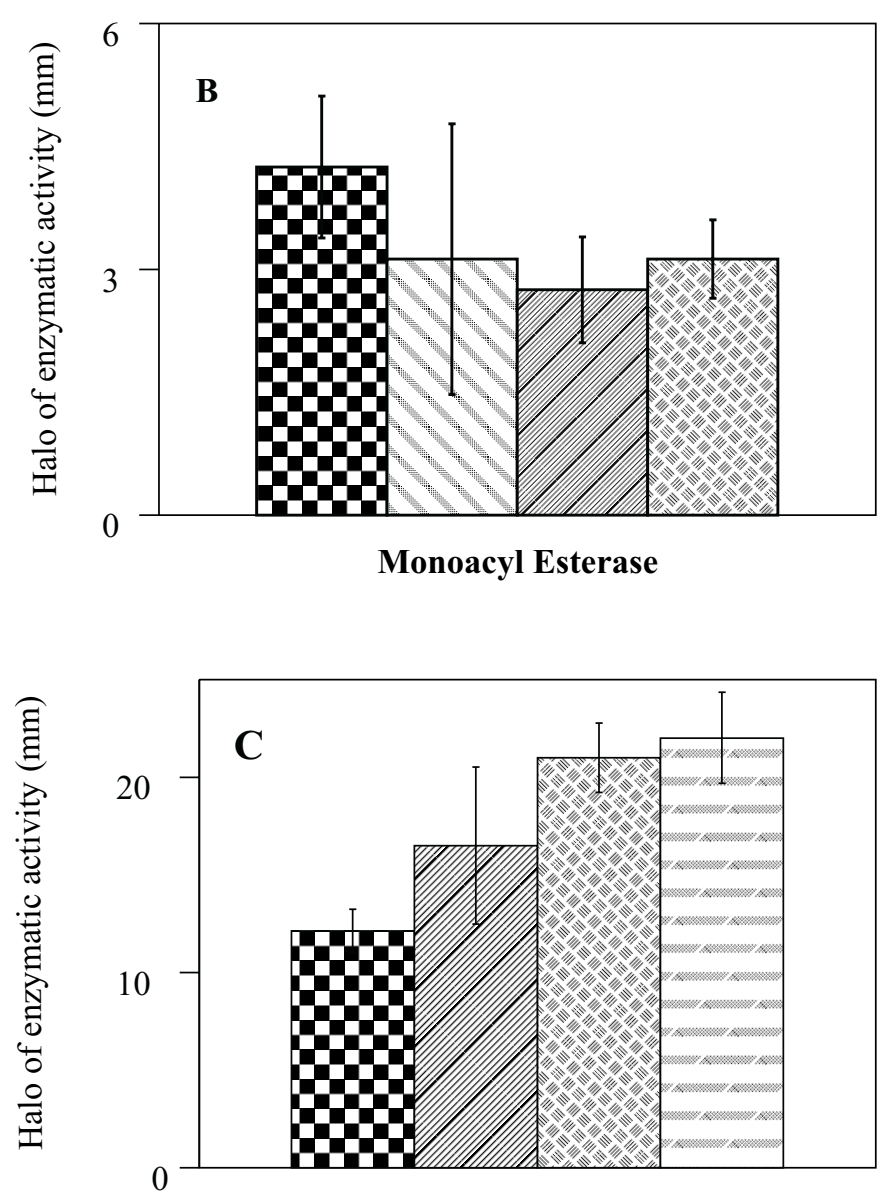

Amylase

Figure 6. Production of extracellular hydrolytic enzymes in semisolid media produced by Cladosporum herbarum isolates (A, B) and Trichoderma species (C). In (A) and (B) from left to right, isolates Ch-1, Ch-2, Ch-3 and Ch-5 of C. herbarum. In (C) from left to right T. harzianum; T. koningii; T. polysporum; T. viride. The halo of enzymatic activity does not include the halo of the mycelium disc.

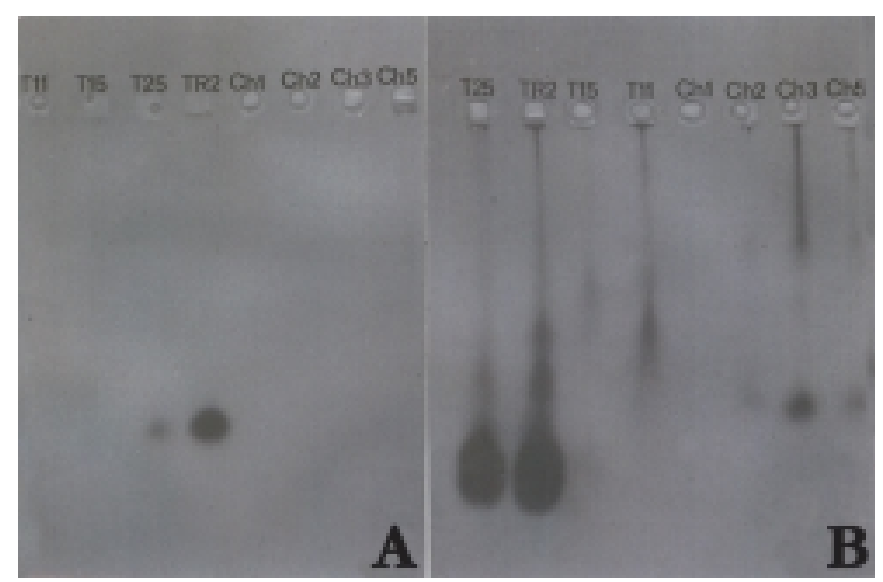

Figure 7. Esterase patterns of Cladosporium herbarum isolates (Ch1, Ch2, Ch3, Ch5), and Trichoderma species $(\mathrm{T} 11=T$. polysporum, $\mathrm{T} 15=T$. koningii, $\mathrm{T} 25=T$. harzianum, $\mathrm{TR} 2=T$. viride), after five days of incubation, in PD medium (A) and mycelial mass washed with EDTA (B).

Trichoderma species and C. herbarum isolates, respectively. In the zymogram, considerably more activity was seen after washing the mycelia in $2 \mathrm{mM}$ EDTA, as compared to the untreated culture fluid (Fig. 7 A, B).

\section{DISCUSSION}

This study has shown that colonies of Trichoderma species grew always faster than $C$. herbarum, in single or mixed culture. Its rapid growth gives Trichoderma an important advantage in the competition for space and nutrients with plant pathogenic fungi, even before it deploys its arsenal of mycotoxins $(10,11)$. Toxic action was evident in various alterations of the hyphal structure of $C$. herbarum grown together with Trichoderma species, similar to the effects described in other systems of mixed cultures $(14,30)$. The species of Trichoderma are known to produce a number of antibiotics, such as trichodermin, trichodermol, harzianum A and harzianolide $(7,17)$. These compounds were responsible for most of the inhibition of $C$. herbarum seen in this work, and observed in other experiments involving biocontrol of fungal phytopathogens $(5,14,25,33)$. Volatile antifungals, among which 6-pentyl-2-pyrone is the best known substance (6) were much less effective against this particular phytopathogen, although other species seem to be rather susceptible $(27,44)$. In any case, the pattern of highly specific inhibition caused by the four Trichoderma species, that permitted differentiate individual isolates of $C$. herbarum shows the intricacies of antagonistic action, considering complex phenomena such as growth and sporulation.

The method of Hankin and Anagnostakis (26) was used to detect the secretion of extracellular cell wall degrading enzymes, both by the isolates of $C$. herbarum and Trichoderma species. 
These assays measured, the combined activity of various enzymes upon pectin and cellulose, respectively (2). Since both pectinolytic and cellulolytic enzymes would be needed for pathogenic action as well as for saprophytic activity, it is difficult to explain the apparent lack of pectinase in the T. koningii isolate. On the other hand, the difference in cellulolytic activity found between Trichoderma species and C. herbarum, though statistically significant, has probably no important biological meaning.

The very different production of amylase by Trichoderma and Cladosporium was already observed by Hankin and Anagnostakis (26), and it may be speculated, that ready expression of amylolytic enzymes is partially responsible for the rapid growth of Trichoderma species in the standard potato-dextrose broth. In contrast, there is no immediate explanation for the fact that the isolates of $C$. herbarum produced much more protease and monoacyl esterase than Trichoderma species, as demonstrated by the agar plate assay. No was investigate a possible attachment of enzymes to the mycelium as the reason for obtaining a negative result, as was suggested with esterases. Nevertheless, the same discrepancy was detected between Trichoderma species and $C$. herbarum, using a different kind of lipase assay (results not shown) than the method employed for monoacyl esterase, because it has been argued that soluble substrates are possibly not a good assay for lipase activity $(29,41)$. Since $C$. herbarum is known to spoil butter and to damage oil paintings (16) it is quite possible that this organism secrets lipase. On the other hand, there is evidence that at least part of the activity measured in all acyl esterase assays is in fact cutinase, an enzyme responsible for pathogenicity of Colletotrichum gloeosporioides on Carica papaya and other plants $(18,28)$. Even so, in the case of $C$. herbarum, the monoacyl esterase detected in fungal culture certainly contains insufficient cutinase activity to allow the pathogen to attack undamaged leaves or fruits of Passiflora edulis.

Zymograms of esterase isoenzymes are useful as additional parameters to distinguish microbial isolates. An apparent lack of extracellular esterases in $C$. herbarum was in fact due to enzymes that could be recovered by washing the mycelium in EDTA or various detergents (results not shown). As can be seen in Fig. 7, the effect is not limited to the pathogen. The hypothesis of absorved rather than eluted enzymes is favored, because the cells remained viable after the extraction procedure. Addition of EDTA to filtered culture fluid did not reactivate eventually denatured enzymes. However, experiments to test for enzymatic protein in the culture fluid were not performed in order to know if the enzymes lose activity after having been diffused away from the cells that secreted them.

\section{RESUMO}

\section{Antagonismo de espécies de Trichoderma sobre Cladosporium herbarum e suas caracterização enzimática}

O maracujá (Passiflora edulis Sims.), um fruto tropical amplamente consumido, tem sua produção e a qualidade dos seus frutos reduzidos pela verrugose causada por Cladosporium herbarum. Este trabalho objetivou investigar o antagonismo de espécies de Trichoderma (T. polysporum, T.koningii, T. viride e T. harzianum) contra $C$. herbarum, e estudar a produção de enzimas hidrolíticas extracelulares pelo fitopatógeno e antagonistas. Os resultados mostraram considerável potencial antagônico para o biocontrole dos isolados de $C$. herbarum por todas as espécies de Trichoderma, exceto T. koningii. $\mathrm{O}$ efeito mais promissor foi observado para T. polysporum. Em relação ao padrão de esterase obtido por eletroforese em gel de poliacrilamida, a maior atividade apresentada pelos isolados foi observada cinco dias após a incubação. Os isolados de $C$. herbarum produziram enzimas extracelulares, lipase, pectinase, cellulase e protease, todas possivelmente relacionadas ao processo de infecção do hospedeiro. A excreção de amilase que parece não estar associada com fitopatógenos foi detectada nas espécies de Trichoderma, mas não em $C$. herbarum. Além disso, todas as espécies de Trichoderma testadas produziram também celulase e pectinase, exceto T. koningii com relação a esta última enzima. A demonstração de várias isoesterases no zimograma das espécies de Trichoderma e isolados de $C$. herbarum, foi notavelmente melhorada através da lavagem do micélio com detergentes ou EDTA. Este fato sugere que uma grande fração de enzimas extracelulares pode permanecer presa externamente na parede celular fúngica após excreção.

Palavras-chave: Maracujá, controle biológico, enzimas extracelulares, fungos

\section{REFERENCES}

1. Alfenas, A.C.; Peters, I.; Brune, W.; Passador, G.C. Eletroforese de proteínas e isoenzimas de fungos e essências florestais. Edit.Universitária, UFV, Viçosa, 1991, 242p.

2. Annis, S.L.; Goodwin, P.H. Recent advances in the molecular genetics of plant cell wall-degrading enzymes produced by plant pathogenic fungi. European J. Plant Pathol., 103:1-14, 1997.

3. Bitancourt, A.A. Uma nova doença do maracujá. O Biológico, 1:202204, 1935

4. Blakeman, J.P.; Fokkema, N.J. Potential for biological control of plant disease on the phylloplane. Annu. Rev. Phytopathol., 20:167192, 1982.

5. Callegarin, A.M.; Cugguda, L. Terreni repressivi verso Fusarium oxysporum: ricerça preliminari di microorganismi antagonisti. Anal. Fac. Sci. Agr. Stud. Torino, 13:19-33, 1984.

6. Claydon, N.; Allan, M.; Hanson, J.R.; Avent, A.G. Antifungal alkylpyrones of Trichoderma harzianum. Trans. Br. Mycol. Soc., 88:503-513, 1987.

7. Claydon, N.; Hanson, J.R.; Truneh, A.; Avent, A.G. Harzianolide, a butenolide metabolite from cultures of Trichoderma harzianum. Phytochemistry, 30:3802-3803, 1991.

8. Chet, J.; Baker, R. Indication of suppressiveness to Rhizoctonia solani in soil. Phytopathology, 70:994-998, 1980.

9. Commitee on Standadization of Common Names for Plant Diseases. Common names for plant disease. Plant Dis., 72:567574, 1988. 
10. Cook, R.J.; Baker, K.F. The nature apractice of biological control of plant pathogens. APS Press, St. Paul, 1989. 539p.

11. Deacon, J.W.; Berry, L.A. Modes of actions of mycoparasites in relation to biocontrol of soilborne plant pathogens. In: Tjamos, E.C.; Papavizas, G.C.; Cook, R.J. (eds). Biological Control of Plant Diseases. Plenum Press, New York, 1992, p.157-167.

12. Dennis, C.; Webster, J. Antagonistic properties of species-groups of Trichoderma. I. Production of non-volatile antibiotics. Trans. Br. Mycol. Soc., 84:25-39, 1971a.

13. Dennis, C.; Webster, J. Antagonistic properties of species-groups of Trichoderma. II. Production of volatile antibiotics. Trans. Br. Mycol. Soc., 84:41-48, 1971b.

14. Dennis, C.; Webster, J. Antagonistic properties of species-groups of Trichoderma. III. Hyfal interaction. Trans. Br. Mycol. Soc., 57:363369, 1971c.

15. Despoulain, B.; Seigle-Murandi, F.; Steiman, R.; De Giorgis, L. Fungal flora of corn White draff. Cryptogam. Mycol., 11:79-88, 1990.

16. De Vries, G.A. Contribution to the knowledge of the genus Cladosporium, Link ex. Fr. Hollandia Press, Baarn, 1952, 121p.

17. Dickinson, J.M.; Hanson, J.R.; Truneh, A. Metabolites of some biological control agents. Pestic. Sci., 44:389-393, 1995.

18. Dickman, M.B.; Podilha, G.K.; Kolattukudy, P.E. Insertion of a cutinase gene into a wound pathogen enables it to infect intact host. Nature, 342:446-448, 1989.

19. Edington, L.V.; Khew, K.L.; Barron, G.L. Fungitoxic spectrum of benzimidazole compounds. Phytopathology, 61:42-44, 1971.

20. Elad, Y.; Chet, J.; Katan, J. Trichoderma harzianum a biocontrol effective against Sclerotium rolfsii and Rhizoctonia solani. Phytopathology, 70:119-121, 1980.

21. Ellis, M.B. Dematiaceous Hyphomycetes. Commonwealth Mycological Institute, Kew, 1971. 608p.

22. Ellis, M.B. More Dematiaceous Hyphomycetes. Commonwealth Mycological Institute, Kew, 1976. 507p.

23. Fravel, D. Commercial biocontrol products for use against soilborne crop diseases. [on line]. Beltsville: Institute of Plant Science - USDA, 1999. [cited in 0101 99]. Available in the web: http://www.bar.usda.gov/ psi/bpdl/bioprod.htm.

24. Gashe, B.A. Initial observations on the cellulytic activities of some fungal isolates. Mircen J., 4:491-494, 1988.

25. Gupta, V.P.; Govindaiah, A.K.B.; Datta, R.K. Antagonistic potential of Trichoderma and Gliocladium species to Botryodiplodia theobromae infecting mulberry. Indian J. Mycol. and Pl. Pathol., 25:125, 1995.

26. Hankin, L.; Anagnostakis, S.L. The use of solid media for detection of enzyme production by fungi. Mycologia, 67:597-607, 1975.

27. Hutchinson, S.A. Biological activities of volatile fungal metabolites. Ann. Rev. Phytopathology, 11:223-246, 1973.
28. Köller, W.; YAO, C.; Trial, F.; Parker, D.M. Role of cutinase in the invasion of plants. Can. J. Bot., 73 (Suppl.): 1109-1118, 1995.

29. Kouker, G.; Jaeger, K.E. Specific and sensitive plate assay for bacterial lipases. Appl. Environ. Microbiol., 53:211-213, 1987.

30. Lee, Y.A.; Wu, W.S. The antagonisms of Trichoderma spp. And Gliocladium virens against Sclerotinia sclerotiorum. Plant Prot. Bull., 26:293-304, 1984.

31. Lifshitz, R.; Witingham, M.T.; Baker, R. Mechanisms of biological control of pre-emergence damping-off of pea by seed treatment with Trichoderma spp. Phytopathology, 76:720-725, 1986.

32. Lilly, V.G.; Barnett, N.L. Physiology of Fungi. McGraw Hill, New York, 1951, 463p.

33. Lundberg, A.; Unestan, T. Antagonism against Fomes annosus. Comparison between different test methods "in vitro" and "in vivo". Mycopathologia., 70:107-115, 1980.

34. Lynch, J.H. "In vitro" identification of Trichoderma harzianum as a potential antagonist of plant pathogens. Curr. Microbiol., 16:49-53, 1987.

35. Manachini, P.L.; Fortina, M.G.; Parini, C. Purification and properties of an endo-polygalacturonidase produced by Rhizopus stolonifer. Biotech. Lett., 9:219-224, 1987.

36. Mehta, R.D.; Patel, K.A.; Roy, K.K.; Mehta, M.H. Biological control of soilborne plant pathogens with Trichoderma harzianum. Indian J. Mycol. Pl. Pathol., 25:126, 1995.

37. Melo, I.S. Trichoderma e Gliocladium como bioprotetores de plantas. Revs. Anu. Patol. Plantas, 4:261-295, 1996.

38. Montenecourt, B.S.; Eveleigh, D.E. Semi-quantitative plate assay for determination of cellulase production by Trichoderma viride. Appl. Environ. Microbiol., 33:178-183, 1977.

39. Neirotti, E.; Azevedo, J.L. Técnica semiquantitativa de avaliação de produção de celulases em Humicola sp. Rev. Microbiol., 19:78-81, 1988.

40. O’Donnell, J.; Dickinson, C.H. Pathonicity of Alternaria and Cladosporium isolates on Phaseolus. Trans. Br. Mycol. Soc., 74:335342, 1980 .

41. Rapp, P.B.; Backhaus, S. Formation of extracellular lipases by filamentous fungi yeasts, and bacteria. Enzyme Microb. Technol., 14:938-943, 1992.

42. Riker, A.J.; Riker, R.S. Introduction to Research on Plant Diseases. John S. Swift Co., St. Louis, 1936. 117p.

43. Samuels, G.J. Trichoderma: a review of biology and systematics of the genus. Mycol. Res., 100:923-935, 1996.

44. Sarath, G.; De la Motte, R.S.; Wagner, F.W. Protease assay methods. In: Beynon, R.J.; Bond, J.S. (eds). Proteolytic enzymes: a practical approach. University Press, Oxford, 1989, p.25-54. 